\title{
The Effect of Knowledge of Entrepreneurial Support on Entrepreneurial Intention
}

\author{
Dr MJ Malebana \\ Tshwane University of Technology, Department of Management and Entrepreneurship, Faculty of \\ Management Sciences, Private Bag X9496, Polokwane, 0700, South Africa \\ Email: malebanamj@tut.ac.za
}

\section{Doi:10.5901/mjss.2014.v5n20p1020}

\begin{abstract}
The importance of entrepreneurship in job creation and economic development is acknowledged all over the world. Like other countries, the South African government has introduced various support measures to assist individuals who want to start new ventures and existing entrepreneurs who want to grow their businesses. However, it is not known to what extent the knowledge of these support measures influences the intention to start a business. The purpose of this research was to investigate, based on the theory of planned behaviour, whether the knowledge of entrepreneurial support influences entrepreneurial intention and its antecedents, namely the attitude towards becoming an entrepreneur and perceived behavioural control. The study was carried out by means of a survey. A structured questionnaire was used to collect the data. The sample consisted of 329 finalyear commerce students registered at one of the rural universities in South Africa. The Statistical Package for the Social Sciences (SPSS) was used to analyse the data. The results revealed that the knowledge of entrepreneurial support is statistically significantly related to the intention of starting a business. A statistically significant relationship was also found between the knowledge of entrepreneurial support and the antecedents of entrepreneurial intention.
\end{abstract}

Keywords: entrepreneurial support, small business assistance, entrepreneurial intention, theory of planned behaviour, South Africa.

\section{Introduction}

South Africa is currently facing a high unemployment rate of about $35.1 \%$ based on the expanded definition of unemployment (Statistics South Africa, 2014). The South African government views the development of small, medium and micro enterprises (SMMEs) as a key factor in its strategy for job creation and development of the economy (Umsobomvu Youth Fund, 2004; Department of Trade and Industry (DTI), 2013). Since 1994 the country has introduced a number of measures to create an enabling environment for the creation and growth of small businesses (DTI, 2013, 2010, 2005). Despite these initiatives, South Africa had been experiencing low total entrepreneurial activity rates (Simrie, Herrington, Kew \& Turton, 2012; Turton \& Herrington, 2013; Herrington \& Kelley, 2013; Herrington \& Kew, 2014) and $15.4 \%$ of individuals indicated that they have entrepreneurial intentions when compared to other countries that have participated in the 2013 Global Entrepreneurship Monitor study. Entrepreneurial activity in rural areas is also reported to be lower than that of urban areas (Herrington, Kew \& Kew, 2011). Malebana (2014) highlighted the need for research regarding the determinants of entrepreneurship in South Africa, especially with the focus on entrepreneurial intention. The establishment of new ventures by rural people is vital in order to stimulate rural economic development. The formation of new business ventures by entrepreneurs and the reorientation of existing businesses towards entrepreneurial goals are regarded as two mechanisms that can lead to economic growth (Orford, Herrington \& Wood, 2005). Studies that have been conducted in South Africa indicate that the majority of people lack the awareness of government programmes aimed at supporting small businesses (Ladzani \& Netswera, 2005; Molapo, Mears \& Viljoen, 2008; Finmark Trust, 2010) and in some cases these programmes reach only a few individuals, with rural areas being the most disadvantaged (Herrington \& Kew, 2014; Orford et al., 2005; Umsobomvu Youth Fund, 2004).

Given the foregoing, entrepreneurship is considered to be a planned and intentional activity that can be understood by studying individuals' entrepreneurial intentions (Krueger, Reilly \& Carsrud, 2000). Thompson (2009, p. 676) defines entrepreneurial intentions as "self-acknowledged convictions by individuals that they intend to set up new business ventures and consciously plan to do so at some point in the future". Entrepreneurial intentions are considered to be the foundation for understanding the new venture creation process (Liñán, Nabi \& Krueger, 2013; Bird, 1988). This is mostly so because they precede entrepreneurial action (Schlaegel \& Koenig, 2014; Douglas, 2013; Shook, Priem \& McGee, 2003). 
The theory of planned behaviour suggests that individuals' intentions are the most important immediate determinant of whether they will perform a particular action or not (Ajzen, 2005, 2012). Ajzen $(2005,2011)$ suggests that the theory of planned behaviour has important implications for behavioural interventions that have been designed with the main purpose of changing intentions and behaviour. This paper is based on the premise that entrepreneurial support is such kind of an intervention that can be directed at one or more of the antecedents of intentions and behaviour: 1) Attitudes, 2) Subjective norms and 3) Perceived behavioural control. Intentions to engage in the entrepreneurial behaviour are formed based on an individual's favourable or unfavourable evaluation of the behaviour, perceived personal ability or difficulty in performing the behaviour and perceived social pressure to perform or not to perform the behaviour. The design of interventions should focus on factors that could change antecedents of intentions by motivating people to engage in the desired behaviour and ensuring that these intentions are carried out by removing any obstacles that could impede actual control over the behaviour (Ajzen, 2011, 2014).

Without entrepreneurial support potential entrepreneurs will not be able to translate their intentions into new ventures (Henley, 2005). While there could be different terms that refer to support for SMMEs such as small business assistance and business support, Hanlon and Saunders (2007, p. 620) define entrepreneurial support as "... the act of providing an entrepreneur with access to a valued resource". Entrepreneurial support in this study means access to information and finance, training and education programmes, provision of infrastructural facilities, business counselling and mentoring needed by an entrepreneur to act on opportunities and manage the business effectively. While the need to support SMMEs is recognised by both the government and the private sector (Schaper \& Volery, 2007; Boter \& Lundström, 2005), the purpose of this study was to examine the influence of the knowledge of government entrepreneurial support on entrepreneurial intention. Since entrepreneurial intention is the foundation for new venture emergence, entrepreneurial support can play a vital role in the development of entrepreneurial intention. There is lack of knowledge in South Africa regarding the effect of government entrepreneurial support measures on entrepreneurial intention and its antecedents. The findings could be valuable to policymakers in ensuring that their support measures contribute to entrepreneurial activity by influencing the antecedents of entrepreneurial intention and entrepreneurial intention and ultimately the establishment and growth of new ventures. The study is also aimed at filling the current gap in developing countries pertaining to the determinants of entrepreneurial intentions based on the theory of planned behaviour (Malebana, 2014; Nabi \& Liñán, 2011; Nabi \& Holden, 2008).

\section{Literature Review}

This study is based on the premise that entrepreneurial support is a vital component that influences entrepreneurial intention and the success of the potential entrepreneur in executing the entrepreneurial process. The focus of the study is on the effect the knowledge of entrepreneurial support has on entrepreneurial intention as well as two of its antecedents namely, the attitude towards becoming an entrepreneur and perceived behavioural control. The literature review describes the role of entrepreneurial support in encouraging start-ups and the growth of new ventures. The entrepreneurial process and how entrepreneurial support can facilitate this process are explained. It concludes with an overview entrepreneurial support in South Africa.

\subsection{Entrepreneurship and the role of entrepreneurial support}

Governments can support new business start-ups and more business growth by providing entrepreneurship education schemes, subsidising enterprise advice and training, and providing financial support schemes and incubation workspace (Bridge, O'Neill \& Martin, 2009). To be effective, government interventions should improve the level of enterprise, entrepreneurship and/or growth of small businesses and deliver the benefits sought. Boter and Lundström (2005) assert that entrepreneurial support should motivate people to start businesses, provide good opportunities to develop new businesses, and entail support structures for equipping entrepreneurs with the necessary skills. This assertion is supported by Gu, Karoly and Zissimopoulos's (2010) view that entrepreneurial activity is dependent on entrepreneurs who start and manage new ventures. The role of entrepreneurial support in influencing entrepreneurial intention is based on the organising model proposed by Shook et al. (2003) and the GEM approach of describing the entrepreneurship process (Simrie et al., 2012). They both view the development of entrepreneurial intention as the first stage in the new venture creation or entrepreneurship process. Therefore, the entrepreneurial process appears to be a valuable framework for understanding how entrepreneurial behaviour occurs in businesses and how entrepreneurial support can enhance this behaviour. It consists of critical aspects that are relevant for both intending and existing entrepreneurs. 
According to Wickham (2006), the entrepreneurial process is based on four interacting contingencies that include the entrepreneur, an opportunity, resources and a business organisation. Ardichvili, Cardozo and Ray (2003) suggest that new ventures result from successful opportunity development process which includes recognition of an opportunity, its evaluation and development. Entrepreneurial intention is followed by the search for and ultimate discovery of opportunities. Once discovered, entrepreneurs must make decisions on whether or not to exploit those opportunities and how to exploit them (Shook et al., 2003). If entrepreneurs decide to pursue the opportunities, entrepreneurial intention is translated into a new venture through action by an enterprising individual which requires the accumulation of resources. These resources may come from entrepreneurs or other institutions. The need for entrepreneurial support may be driven by the high failure rate of new businesses as reported in the entrepreneurship literature. On the other hand there could be several impediments or obstacles that prevent the implementation of entrepreneurial intentions (Ajzen, 2005, 2011, 2012; Carsrud \& Brännback, 2011). The government should support new and existing businesses to avoid and prevent some of the causes of small business failure and facilitate the implementation of entrepreneurial intentions among intending entrepreneurs.

Nabi, Holden and Walmsley (2006) assert that providing a range of support and resources can influence the startup decision processes by impacting on perceived attractiveness, perceived feasibility, self-efficacy, and propensity to act which in turn lead to the formation of entrepreneurial intentions. Kim and Cho (2009) found that institutional support provided to start-ups leads to the increase in the number of people entering self-employment. Perceived feasibility and desirability of starting a business can be enhanced by the provision of information pertaining to market opportunities and the supply of skilled labour (Begley, Tan \& Schoch, 2005).

\subsection{Entrepreneurial support in South Africa}

In 1995 the South African government published the White Paper on National Strategy on the Development and Promotion of Small Business in South Africa. It articulated measures to foster an enabling environment for small businesses and resulted in the establishment of a number of support institutions and the introduction of various measures to support SMMEs (DTI, 2014, 2010, 2005). These support institutions include the National Small Business Council, Ntsika Enterprise Development Agency, Khula Enterprise Finance, a national grid of local business service centres (LBSCs) and provincial small enterprise desks (DTI, 2004). The National Small Business Act of 1996, amended in 2004 was promulgated in order to create an enabling environment (DTI, 2004). The DTI is the key organisation that provides the national framework for SMME support in South Africa (DTI, 2004). The DTI through its economic cluster has the responsibility to strengthen integrated state financial and business development support for small enterprises through a delivery network of institutions that covers the entire country (DTI, 2007/08). Its agencies include Small Enterprise Finance Agency (SEFA), the Small Enterprise Development Agency (Seda), the National Youth Development Agency (NYDA), the Industrial Development Corporation (IDC), Companies and Intellectual Property Commission (CIPC), Land Bank, Mafisa, Provincial government agencies and the National Empowerment Fund (NEF) (DTI, 2014, 2013, 2007/08). The government support initiatives for SMMEs in South Africa include easing the regulatory and compliance burden on small enterprises, access to finance, business development services, youth enterprise development, support for womenowned enterprises, incubation and technology acquisition and transfer services, productivity enhancement centres and sector-focused support measures.

Given the urgency to create more jobs through SMMEs, the South African government should ensure that its support measures stimulate the formation of entrepreneurial intentions to establish high quality and growth-oriented ventures. This is necessitated by the fact that typical start-ups are less innovative, create few jobs and make little contribution to wealth creation (Shane, 2009). It is also vital that information relating to the various types of support with clear requirements for accessing them is made available (Malebana \& Swanepoel, 2014). The ability to act on entrepreneurial opportunities depends on individuals perceptions regarding their skills to successfully exploit these opportunities (Sriram, Mersha \& Herron, 2007; Arenius \& Minniti, 2005). Since these skills can be enhanced through entrepreneurship education (Malebana \& Swanepoel, 2014; Saeed, Yousafzai, Yani-De-Soriano \& Muffatto, 2013; Zhao, Hills \& Seibert, 2005), the establishment of partnerships between higher education institutions and government institutions to make resources available for students to experiment with their ideas is essential. Perceptions regarding the availability of entrepreneurial support are positively related to entrepreneurial self-efficacy and entrepreneurial intentions (Saeed et al., 2013). Access to and the usage of entrepreneurial support are positively related to entrepreneurial intention and new venture start-up (Delanoë, 2013). Zanakis, Renko \& Bullough (2012) reported that perceived support by nascent entrepreneurs facilitates transition to owning and operating a new venture. By increasing access and awareness of entrepreneurial support government institutions would create what Tang (2008) called a 'munificent environment' which 
increases alertness to entrepreneurial opportunities. This will also be interpreted as a socially supportive culture/institutional environment that had been found to be positively associated with the national entrepreneurship rate (Stephan \& Uhlaner, 2010) and high levels of start-up motivation (Hopp \& Stephan, 2012).

\section{Research Methodology}

\subsection{The sample}

This study was carried out by means of a survey and included 329 third year commerce students at a rural university in the Limpopo Province in South Africa. These students were suitable for studying entrepreneurial intentions because they had to make important career decisions on completion of their studies, of which entrepreneurship was considered one of them. This is in line with other similar studies such as (Krueger et al., 2000; Liñán \& Chen, 2009; Liñán et al., 2013).

\subsection{Data collection}

Data were collected using a structured questionnaire that was distributed to students during their lectures. The questionnaire was developed from Liñán and Chen's (2009) Entrepreneurial Intention Questionnaire that was developed solely to measure entrepreneurial intention and its determinants based on Ajzen's theory of planned behaviour (Liñán, Urbano \& Guerrero, 2011). The questionnaire consisted of questions that were based on the seven-point Likert scale (1=Strongly disagree and 7=Strongly agree) and nominal scales. Likert scale type questions were used for entrepreneurial intention (four items), attitude towards becoming an entrepreneur (five items), perceived behavioural control (seven items) and entrepreneurial support (five items). Questions on entrepreneurial support were developed from Zanakis et al. (2012) and Liao and Welsch (2005). They involved the knowledge of available support and the level of knowledge about the types of support available, the adequacy of support, perceived difficulty to access information about support measures and perceived quality of available entrepreneurial support. Data on the characteristics of the sample were collected using nominal scales. The reliability of the measuring instrument was tested by means of Cronbach Alpha. Cronbach's alpha scores were .750 for entrepreneurial intention, .766 for the attitude towards becoming an entrepreneur, .762 for perceived behavioural control and .702 for entrepreneurial support (Table 1). Since Cronbach's alpha scores of the data collection instrument were higher than 0.60 as suggested by Garson (2009), it was considered a reliable tool for use in this research. To ensure reliability of the results the questionnaire was also pre-tested on five students from the targeted population and the responses were satisfactory.

Table 1: Measures of entrepreneurial intention, attitude towards becoming an entrepreneur, perceived behavioural control and knowledge of entrepreneurial support

\begin{tabular}{|c|c|c|}
\hline Variable & Items & Cronbach's alpha \\
\hline Entrepreneurial intention & $\begin{array}{l}\text { 1. I am ready to do anything to be an entrepreneur. } \\
\text { 2. } \text { My professional goal is to be an entrepreneur. } \\
\text { 3. I will make every effort to start and run my own business. } \\
\text { 4. I am determined to create a business venture in the future. }\end{array}$ & 0.750 \\
\hline $\begin{array}{l}\text { Attitude towards becoming an } \\
\text { entrepreneur }\end{array}$ & 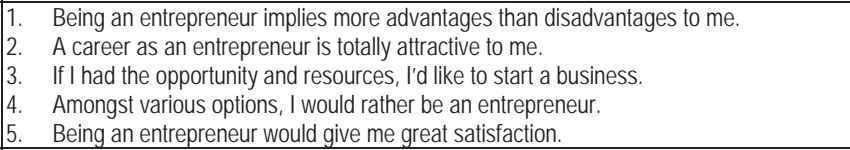 & 0.766 \\
\hline Perceived behavioural control & 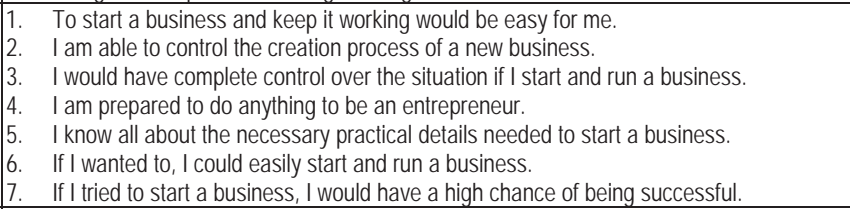 & 0.762 \\
\hline $\begin{array}{l}\text { Knowledge of entrepreneurial } \\
\text { support }\end{array}$ & $\begin{array}{l}\text { 1. I know the different types of support offered to people who want to start new } \\
\text { businesses. } \\
\text { 2. Information about government support is accessible. } \\
\text { 3. My level of knowledge about the types of support offered to people who want to start a } \\
\text { business is high. } \\
\text { 4. The government provides adequate support to start a business. } \\
\text { 5. The government provides quality support to start a business. }\end{array}$ & 0.702 \\
\hline
\end{tabular}




\subsection{Data analysis}

The Statistical Package for the Social Sciences (SPSS) was used to analyse the data. Descriptive statistics were used to analyse the data relating to the characteristics of the sample. Pearson correlation and Somer's $d$ test statistic were used to analyse the relationship between the knowledge of entrepreneurial support and entrepreneurial intention as well as its antecedents. The differences in entrepreneurial intention, the attitude towards becoming an entrepreneur and perceived behavioural control based on the respondents' knowledge of enterpreneurial support was tested using Man-Whitney $U$ test.

\section{Results and Discussion}

\subsection{Characteristics of the sample}

Of the 329 respondents $57.1 \%$ were female and $41.9 \%$ were male. In terms of age $24.6 \%$ were in the age category between 18 and 21 years, $61.1 \%$ of the respondents were in the age category between 22 and 25 years, $7.6 \%$ were in the age category between 26 and 30 years, $2.7 \%$ were in the age category between 31 and 35 years, while $2.7 \%$ were above 36 years. In terms of exposure to entrepreneurship education, $42.6 \%$ of the respondents have had a one year module in entrepreneurship while $57.1 \%$ did not have this exposure. Seven percent of the respondents were currently running their own businesses, $32.8 \%$ had tried to start a business before while $28.6 \%$ were coming from the families with members who are running businesses. Descriptive statistics and correlations among variables are shown in Table 2 . The findings revealed that exposure to an entrepreneurship module, being from an entrepreneurial family background and having tried to start a business before are significantly correlated with entrepreneurial intention $(p<.01)$, the attitude towards becoming an entrepreneur $(p<.01)$ and perceived behavioural control $(p<.01)$. Knowledge of entrepreneurial support had a significant correlation with exposure to an entrepreneurship module $(p<.01)$, being from an entrepreneurial family background $(p<.05)$, entrepreneurial intention $(p<.01)$, the attitude towards becoming an entrepreneur $(p<.01)$ and perceived behavioural control $(p<.01)$.

Table 2: Descriptive statistics and correlations among variables

\begin{tabular}{|c|c|c|c|c|c|c|c|c|c|c|c|c|}
\hline & Mean & SD & 1 & 2 & 3 & 4 & 5 & 6 & 7 & 8 & 9 & 10 \\
\hline 1. Gender & 1.56 & .515 & 1 & & & & & & & & & \\
\hline 2. Age & 1.94 & .852 & .033 & 1 & & & & & & & & \\
\hline 3. Did you do a module in entrepreneurship? & 1.57 & .496 & .027 & .050 & 1 & & & & & & & \\
\hline 4. Are you currently running a business? & 1.92 & .287 & .042 & -.105 & .092 & 1 & & & & & & \\
\hline 5. Is anyone in your family running a business? & 1.71 & .461 & .083 & -.019 & $.218^{* *}$ & $.133^{*}$ & 1 & & & & & \\
\hline 6. Have you ever tried to start a business before? & 1.65 & .495 & $.133^{*}$ & $-.134^{*}$ & .101 & $.286^{* *}$ & $.242^{* *}$ & 1 & & & & \\
\hline 7. Entrepreneurial intention & 2.22 & .960 & -.022 & -.022 & $-.219^{* *}$ & -.061 & $-.174^{* *}$ & $-.173^{* *}$ & 1 & & & \\
\hline 8. Attitude towards becoming an entrepreneur & 2.20 & .952 & -.066 & -.038 & $-.222^{* *}$ & -.055 & $-.178^{* *}$ & $-.173^{* *}$ & $.645^{* *}$ & 1 & & \\
\hline 9. Perceived behavioural control & 2.10 & .977 & -.061 & -.063 & $-.191^{* *}$ & -.017 & $-.154^{* *}$ & $-.201^{* *}$ & $.572^{* *}$ & $.546^{* *}$ & 1 & \\
\hline 10. Knowledge of entrepreneurial support & 2.02 & .974 & .019 & .034 & $-.157^{* \star}$ & .015 & $-.119^{*}$ & -.071 & $.244^{* *}$ & $.220^{* *}$ & $.261^{* t}$ & 1 \\
\hline
\end{tabular}

\subsection{The respondents' knowledge of entrepreneurial support}

The findings (Table 3) show that close to 57\% (percentages of 'agreed', 'strongly agreed' and 'totally agreed' combined) of the respondents knew the different types of support that are offered to people who want to start businesses while $52.6 \%$ believed that information about these types of support is accessible. Over $59 \%$ of the respondents perceived their knowledge about the types of support offered to people who want to start a business to be high. The majority of the respondents (65\% and $56 \%$ respectively) were convinced that there is adequate government support for people who want to start new businesses and that the government provides quality support to start a business. Since the issue of low level of awareness of entrepreneurial support in South Africa among entrepreneurs has been documented in previous research, the findings should be interpreted with caution as the respondents could have been exposed to these support measures through other means such as entrepreneurship education. Maybe the results could have been different if the respondents were asked questions about their knowledge of specific types of support or services instead of general 
knowledge questions.

Table 3: The respondents' knowledge of entrepreneurial support

\begin{tabular}{|c|c|c|c|c|c|c|c|c|c|c|}
\hline \multirow{2}{*}{ Entrepreneurial support } & \multirow{2}{*}{$\mathrm{N}$} & \multicolumn{7}{|c|}{ Percentage (\%) } & \multirow{2}{*}{ Mean } & \multirow{2}{*}{$\begin{array}{l}\text { Standard } \\
\text { Deviation }\end{array}$} \\
\hline & & ${ }^{*} \mathrm{TD}$ & *SD & ${ }^{*} \mathrm{D}$ & ${ }^{*} \mathrm{~N}$ & ${ }^{*} \mathrm{~A}$ & *SA & ${ }^{*} \mathrm{TA}$ & & \\
\hline $\begin{array}{l}\text { * I know the different types of support offered to people who want } \\
\text { to start new businesses }\end{array}$ & 304 & 5.2 & 1.5 & 9.4 & 19.5 & 18.8 & 14.3 & 23.7 & 4.60 & 2.09 \\
\hline * Information about government support is accessible & 323 & 14.0 & 6.4 & 10.0 & 15.2 & 12.5 & 7.9 & 32.2 & 4.53 & 2.23 \\
\hline $\begin{array}{l}\text { * My level of knowledge about the types of support offered to } \\
\text { people who want to start a business is high }\end{array}$ & 317 & 10.0 & 5.8 & 9.7 & 10.6 & 10.9 & 10.9 & 38.3 & 4.82 & 2.27 \\
\hline * The government provides adequate support to start a business & 326 & 9.1 & 4.6 & 7.6 & 12.8 & 11.6 & 11.6 & 41.9 & 5.13 & 2.08 \\
\hline * The government provides quality support to start a business & 305 & 7.3 & 4.6 & 7.6 & 17.0 & 21.0 & 11.9 & 23.4 & 4.47 & 2.16 \\
\hline
\end{tabular}

* Some of the percentages of entrepreneurial support factors do not add up to $100 \%$ owing to missing data. ${ }^{*} T \mathrm{~T}=\mathrm{Totally}$ disagree, $\mathrm{SD}=$ Strongly disagree, $\mathrm{D}=\mathrm{Dis}$ gree, $\mathrm{N}=$ Neutral, $\mathrm{A}=$ Agree, $\mathrm{SA}=$ Strongly agree \& $\mathrm{TA}=$ Totally agree.

\subsection{The knowledge of entrepreneurial support and entrepreneurial intention}

The results (Table 4) revealed that a statistically significant relationship exists between the knowledge of entrepreneurial support and entrepreneurial intention $(p<.000)$. This knowledge is also significantly related to the attitude towards becoming an entrepreneur $(p<.000)$ and perceived behavioural control $(p<.000)$. However, these relationships were considered to be weak given Somer's $d$ values of less than 0.4 . The results indicate that more efforts to increase the knowledge of entrepreneurial support and make information about this support accessible are necessary in order to increase the number of people with the intention to start a business. These efforts will also generate positive entrepreneurial attitudes and enhance perceived behavioural control. Thus the more knowledge individuals have about the available entrepreneurial support the more likely they would find the entrepreneurial career attractive and perceive the act of starting a business doable.

Table 4: The relationship between entrepreneurial support, entrepreneurial intention, the attitude towards becoming an entrepreneur and perceived behavioural control

\begin{tabular}{|c|c|c|}
\hline & Somer's d value & $P$ value \\
\hline Entrepreneurial intention & 0.222 & $0.000 * \star \star$ \\
\hline Attitude towards becoming an entrepreneur & 0.209 & $0.000 * \star \star$ \\
\hline Perceived behavioural control & 0.246 & $0.000 * \star *$ \\
\hline
\end{tabular}

Furthermore, Mann-Whitney $U$ test was used to determine whether the respondents with low and high levels of knowledge of entrepreneurial support were significantly different in entrepreneurial intention, the attitude towards becoming an entrepreneur and perceived behavioural control. The respondents with high levels of knowledge of entrepreneurial support were significantly different from those with low levels of knowledge in entrepreneurial intention, the attitude towards becoming an entrepreneur and perceived behavioural control (Table 5). The mean rank values of the respondents with high levels of knowledge of entrepreneurial support were significantly higher than those with low levels of knowledge. The findings suggest that raising awareness of entrepreneurial support can contribute positively to the formation of entrepreneurial intention, generate positive entrepreneurial attitudes and enhance perceived capability of starting a business.

Table 5: Differences in entrepreneurial intention, the attitude towards becoming an entrepreneur and perceived behavioural control based the level of knowledge about entrepreneurial support

\begin{tabular}{|l|c|c|}
\hline & Mean rank & p-value \\
\hline Entrepreneurial intention & $\begin{array}{l}\text { Low level of knowledge }=136.53 \\
\text { High level of knowledge }=174.85\end{array}$ & $0.000^{\star \star \star}$ \\
\hline Attitude towards becoming an entrepreneur & $\begin{array}{l}\text { Low level of knowledge }=137.78 \\
\text { High level of knowledge }=173.65\end{array}$ & $0.000^{\star \star *}$ \\
\hline Perceived behavioural control & $\begin{array}{l}\text { Low level of knowledge }=134.49 \\
\text { High level of knowledge }=176.83\end{array}$ & $0.000^{\star \star \star}$ \\
\hline
\end{tabular}




\section{Conclusions and Recommendations}

The purpose of this study was to investigate the influence of the knowledge of government entrepreneurial support on the intention to start a business among rural university students in South Africa. The findings revealed that the respondents' knowledge of entrepreneurial support is significantly associated with their attitude towards becoming an entrepreneur and perceived behavioural control and their intention to start a business. The results suggest that entrepreneurial support can be one of the valuable tools to stimulate entrepreneurial intention. Since entrepreneurial intention precedes entry into selfemployment, these findings support those of Kim and Cho (2009). The results indicate that entrepreneurial support can facilitate the start-up decision process by impacting on entrepreneurial intention and its antecedents as pointed out by Nabi et al. (2006).

The findings suggest that efforts to stimulate rural entrepreneurial activity in South Africa are more likely to succeed if campaigns to raise awareness of and access to entrepreneurial support could be intensified. This view is in line with previous research findings that have indicated the relationship between perceived availability of entrepreneurial support and entrepreneurial self-efficacy, entrepreneurial intentions (Saeed et al., 2013), new venture start-up (Delanoë, 2013) and transition to owning and operating a new venture (Zanakis et al., 2012). The establishment of new and growth of existing ventures by entrepreneurs in rural areas is vital in creating jobs and stimulating rural economies (Malebana, 2014). As a result more targeted entrepreneurial support should be directed to intending entrepreneurs in these areas so that they can contribute to job creation (Douglas, 2013).

As South African GEM reports have indicated, the effectiveness of entrepreneurial support is hampered by political appointees who have little or no knowledge of entrepreneurship (Herrington \& Kew, 2014; Herrington et al., 2011). Since it is believed that entrepreneurial support will help to rid unemployment by creating new and growing existing ventures, the use of political appointees only worsens the unemployment situation and leads to misuse of valuable SMME support resources. Therefore, suitably qualified professionals should be appointed to deliver the right support to entrepreneurs and ensure its accessibility.

The findings suggest that theory of planned behaviour could be a valuable tool for evaluating the impact of entrepreneurial support programmes on the intention of starting a business. For example, it can be used to assess the impact of entrepreneurial support programmes on changing the antecedents of entrepreneurial intention and ultimately entrepreneurial behaviour (Ajzen, 2011). Studies on entrepreneurial intention are still very few in South Africa. Therefore, there is a need for more knowledge regarding the factors influencing the antecedents of entrepreneurial intention and intention. Future research can apply entrepreneurial intention models to examine for example, the impact of entrepreneurial support on the establishment of new ventures and small business growth. The researcher was only interested in whether awareness of entrepreneurial support influences the intention to start a business. Owing to the different types of entrepreneurial support that are offered by the government, this study did not clearly specify the types of support that could be required by entrepreneurs when starting a business. This would need to be addressed in future studies.

The shortcomings of this study lie in its cross-sectional nature and convenience sampling. It is therefore impossible to infer causal relationships and actual behaviour. Owing to the use of a convenience sample the results cannot be generalised to all rural university students in South Africa.

\section{References}

Ajzen, I. (2005). Attitudes, personality and behaviour. (2nd ed.). Open University Press, Berkshire, England.

Ajzen, I. (2011). Behavioural interventions: Design and evaluation guided by the theory of planned behaviour. In M.M. Mark., S.I. Donaldson, \& B.C. Campbell (Eds.), Social psychology for program and policy evaluation (pp. 74-100). New York: Guilford.

Ajzen, I. (2012). The theory of planned behaviour, In Lange, P A. M., Kruglanski, A. W. \& Higgins, E. T. (Eds.), Handbook of theories of social psychology (Vol. 1, pp 438-459). London, UK: Sage.

Ajzen, I. (2014). The theory of planned behaviour is alive and well, and not ready to retire: a commentary on Sniehotta, Presseau, and Araujo-Soares. Health Psychology Review. [Online] Available at: http://dx.doi.org/10.1080/17437199.2014.883474 (13 April 2014).

Ardichvili, A., Cardozo, R. \& Ray, S. (2003). A theory of entrepreneurial opportunity identification and development. Journal of Business Venturing, 18, 105-123.

Arenius, P. \& Minniti, M. (2005). Perceptual variables and nascent entrepreneurship. Small Business Economics, 24, 233-247.

Begley, T. M., Tan, W. \& Schoch, H. (2005). Politico-economic factors associated with interest in starting a business: A multi-country study. Entrepreneurship Theory \& Practice, January, 35-51.

Bird, B. (1988). Implementing entrepreneurial ideas: The case for intention, The Academy of Management Review, 13(3), 442-453. 
Boter, H. \& Lundström, A. (2005). SME perspectives on business support services: The role of company size, industry and location. Journal of Small Business \& Enterprise Development, 12(2), 244-258.

Bridge, S., O'Neill, K. \& Martin, F. (2009). Understanding enterprise, entrepreneurship and small business, (3rd ed.). Houndmills, Basingstoke: Palgrave Macmillan.

Carsrud, A. \& Brännback, M. (2011). Entrepreneurial motivations: What do we still need to know? Journal of Small Business Management, 49(1), 9-26.

Delanoë, S. (2013). From intention to start-up: the effect of professional support. Journal of Small Business \& Enterprise Development, 20(2), 383-398.

Department of Trade and Industry. (2004). Review of ten years of small business support in South Africa 1994-2004. [Online] Available at: http://www.tips.org.za/files/10_years_of_Small_Business_support_in_South_Africa.pdf (29 May 2009).

Department of Trade and Industry. (2005). SMME-Integrated strategy on the promotion of entrepreneurship and small enterprises. [Online] Available at: http://www.thedti.gov.za (16 March 2008).

Department of Trade and Industry. (2007/08). Department of Trade and Industry Annual report 2007/08. [Online] Available at: http://www.dti.gov.za/publications/annual report0708.pdf (26 September 2009).

Department of Trade and Industry. (2010). National Directory of Small Business Support Pogrammes. [Online] Available at: http://www.dti.gov.za (02 April 2013).

Department of Trade and Industry. (2013). Youth Enterprise Development Strategy 2013-2023. [Online] Available at: http://www.dti.gov.za (13 March 2014).

Department of Trade and Industry. (2014). Institutional support for small medium micro enterprise development. [Online] Available at: http://www.dti.gov.za/sme_development/inst_support.jsp (26 June 2014).

Douglas, E.J. (2013). Reconstructing entrepreneurial intentions to identify predisposition for growth. Journal of Business Venturing, 28, 633-651.

FINMARK TRUST. (2010). FinScope South Africa Small Business Survey 2010. [Online] Available at: http://www.dti.gov.za/DownloadFileAction?id=382 (02 April 2013).

Gu, Q., Karoly, L. A. \& Zissimopoulos, J. (2010). Small business assistance programs in

the United States: An analysis of what they are, how well they perform, and how we can learn more about them. International Review of Entrepreneurship, 8(3), 199-230.

Hanlon, D. \& Saunders, C. (2007). Marshalling resources to form small new ventures: Toward a more holistic understanding of entrepreneurial support. Entrepreneurship Theory \& Practice, July, 619-641.

Henley, A. (2005). From entrepreneurial aspiration to business start-up: Evidence from British longitudinal data, [Online] Available at: http://www.swan.ac.uk/sbe/research/working\%20papers/SBE\%202005\%202.pdf (01 November 2007).

Herrington, M. \& Kelley, D. (2013). African entrepreneurship - Sub-Saharan African Regional Report 2012. [Online] Available at: http://gemconsortium.org/docs/download/2909 (21 March 2014).

Herrington, M. \& Kew, J. (2014). GEM South Africa 2013 Report. [Online] Available at: http://www.gemconsortium.org/docs/3336/gemsouth-africa-2013-report (30 April 2014).

Herrington, M., Kew, J. \& Kew, P. (2011). Global Entrepreneurship Monitor-2010 South African Report. [Online] Available at: http://www.gemconsortium.org/files.aspx?Ca_ID=126 (26 August 2011).

Hopp, C. \& Stephan, U. (2012). The influence of socio-cultural environments on the performance of nascent entrepreneurs: Community culture, motivation, self-efficacy and start-up success. Entrepreneurship \& Regional Development: An International Journal, 24(910), 917-945

Kim, G. \& Cho, J. (2009). Entry dynamics of self-employment in South Korea. Entrepreneurship \& Regional Development, 21(3), 303323.

Krueger, N.F., Reilly, M.D. \& Carsrud, A.L. (2000). Competing models of entrepreneurial intentions. Journal of Business Venturing, 15, 411-432.

Ladzani, M. W. \& Netswera, F. G. (2005). Entrepreneurial support for rural small, medium and micro enterprises (SMMEs) in South Africa. [Online] Available at: http://www.sbaer.uca.edu/research/icsb/2005/199.pdf (09 March 2007).

Liñán, F. \& Chen, Y. (2009). Development and cross-cultural application of a specific instrument to measure entrepreneurial intentions. Entrepreneurship Theory \& Practice, May, 593-617.

Liñán, F., Nabi, G. \& Krueger, N. (2013). British and Spanish entrepreneurial intentions: A comparative study. Revista De Economia Mundial, 33, 73-103.

Liñán, F., Urbano, D. \& Guerrero, M. (2011). Regional variations in entrepreneurial cognitions: Start-up intentions of university students in Spain. Entrepreneurship \& Regional Development, 23(3), 187-215.

Liao, J. \& Welsch, H. (2005). Roles of social capital in venture creation: Key dimensions and research implications. Journal of Small Business Management, 43(4), 345-362.

Malebana, J. (2014). Entrepreneurial intentions of South African rural university students: A test of the theory of planned behaviour. Journal of Economics \& Behavioral Studies, 6(2), 130-143.

Malebana, M.J. \& Swanepoel, E. (2014). The relationship between exposure to entrepreneurship education and entrepreneurial selfefficacy. Southern African Business Review, 18(1), 1-26.

Molapo, S., Mears, R. \& Viljoen, J.M.M. (2008). Developments and reforms in small business support institutions since 1996. Acta Commercii, 8(1), 27-40. 
Nabi, G. \& Holden, R. (2008). Graduate entrepreneurship: intentions, education and training. Education \& Training, 50(7), 545-551.

Nabi, G., Holden, R. \& Walmsley, A. (2006). Graduate career-making and business start-up: A literature review. Education \& Training, 48(5), 373-385.

Nabi, G. \& Liñán, F. (2011). Graduate entrepreneurship in the developing world: intentions, education and development. Education \& Training, 53(5), 325-334

Orford, J., Herrington, M. \& Wood, E. (2005). Global Entrepreneurship Monitor-2004 South African Executive Report. [Online] Available at: http://www.gemconsortium.org/docs/600/gem-south-africa-2004-report (02 April 2013).

Saeed, S., Yousafzai, S.Y., Yani-De-Soriano, M. \& Muffatto, M. (2013). The role of perceived university support in the formation of students' entrepreneurial intention. Journal of Small Business Management, doi: 10.1111/jsbm.12090.

Schaper, M. \& Volery, T. (2007). Entrepreneurship and small business. (2nd Pacific Rim ed.). Singapore: John Wiley \& Sons.

Schlaegel, C. \& Koenig, M. (2014). Determinants of entrepreneurial intent: A meta-analytic test and integration of competing models. Entrepreneurship Theory \& Practice, March, 291-332.

Shane, S. (2009). Why encouraging more people to become entrepreneurs is a bad policy. Small Business Economics, 33, $141-149$.

Shook, C.L., Priem, R.L. \& McGee, J.E. (2003). Venture creation and the enterprising individual: A review and synthesis. Journal of Management, 29(3), 370-399.

Simrie, M., Herrington, M., Kew, J. \& Turton, N. (2012). GEM South Africa 2011 Report. [Online] Available at: http://www.gemconsortium .org/docs/2313/gem-south-africa-2011-report (26 October 2012).

Sriram, V., Mersha, T. \& Herron, L. (2007). Drivers of urban entrepreneurship: An integrative model. International Journal of Entrepreneurial Behaviour \& Research, 13(4), 235-251.

Statistics South Africa. (2014). Labour Force Survey, Quarter 1. [Online] Available at: http://beta2.statssa.gov.za /publications/P0211/P02111stQuarter2014.pdf (07 June 2014).

Stephan, U. \& Uhlaner, L.M. (2010). Performance-based vs socially supportive culture: A cross-national study of descriptive norms and entrepreneurship. Journal of International Business Studies, 41, 1347-1364.

Tang, J. (2008). Environmental munificence for entrepreneurs: Entrepreneurial alertness and commitment. International Journal of Entrepreneurial Behaviour \& Research, 14(3), 128-151

Thompson, E. R. (2009). Individual entrepreneurial intent: Construct clarification and development of an internationally reliable metric. Entrepreneurship Theory \& Practice, May, 669-694.

Turton, N. \& Herrington, M. (2013). Global Entrepreneurship Monitor 2012-South Africa. [Online] Available at: http://www.gemconsortium .org/docs/2801/gem-south-africa-2012-report (20 May 2013).

Umsobomvu Youth Fund (2004). Building an entrepreneurial culture. Paper presented at the Youth Entrepreneurship Conference held at the Sandton Convention Centre, Gauteng, 28-29 June 2004.

Wickham, P.A. (2006). Strategic entrepreneurship. (4th ed.). England: Pearson Education.

Zanakis, S.H., Renko, M. \& Bullough, A. (2012). Nascent entrepreneurs and the transition to entrepreneurship: Why do people start new businesses? Journal of Developmental Entrepreneurship, 17(1), 1-25.

Zhao, H., Hills, G.E. \& Seibert, S.E. (2005). The mediating role of self-efficacy in the development of entrepreneurial intentions. Journal of Applied Psychology, 90(6), 1265-1272. 